\title{
Nilai Sosial dan Nilai Politik dalam Kumpulan Puisi Nyanyian Akar Rumput
}

\author{
Muhamad Izwar ${ }^{1}$, Rusdiawan ${ }^{2}$, Ida Bagus Kade Gunayasa ${ }^{3}$ \\ Magister Pendidikan Bahasa Indonesia, Universitas Mataram \\ izwarmuhamad@gmail.com
}

\begin{abstract}
This research is about the social values and political values of Wiji Thukul's poems in the anthology Nyanyian Akar Rumput. Therefore, this research aims to describe the forms of social values and political values of Wiji Thukul's poems in the anthology Nyanyian Akar Rumput. As for the method of data collection are literature studies and observations. Observation method is taken by reading and identifying. While descriptive analysis method is used to analyzing data. Based on the result of data analysis, the forms of social values of Wiji Thukul's poems in the anthology Nyanyian Akar Rumput is about responsibility, caring, and justice. While the forms of political values is about struggle, persuasion, and protest.

Keywords: Value; social; politic; poetry; hermeneutica.
\end{abstract}

\section{Intisari}

Masalah dalam penelitian ini adalah tentang nilai sosial dan nilai politik puisi-puisi karya Wiji Thukul dalam antologi puisi Nyanyian Akar Rumput. Oleh karena itu, penelitian ini bertujuan untuk memaparkan bentuk-bentuk nilai sosial dan nilai politik puisi-puisi karya Wiji Thukul dalam antologi puisi Nyanyian Akar Rumput. Adapun metode pengumpulan data yang digunakan dalam penelitian ini yakni studi pustaka dan observasi. Metode observasi yang dilakukan dalam penelitian ini ditempuh melalui kegiatan membaca dan mengidentifikasi. Sedangkan metode deskriptif analisis dilakukan dalam menganalisis data. Berdasarkan hasil analisis data yang telah dilakukan, wujud nilai sosial yang ditemukan pada puisi-puisi karya Wiji Thukul dalam antologi puisi Nyanyian Akar Rumput berbentuk tanggung jawab, kepedulian, dan keadilan. Sedangkan wujud nilai politik yang ditemukan pada puisi-puisi karya Wiji Thukul dalam antologi puisi Nyanyian Akar Rumput berbentuk perjuangan, persuasi, dan protes.

Kata kunci: Nilai; sosial; politik; puisi; hermeneutika.

\section{Pendahuluan}

Puisi merupakan karya cipta dari seorang penyair yang dituangkan dalam bentuk tulisan.

Dalam penciptaan sebuah puisi, penyair biasanya mendapatkan ide dari peristiwa konkret di sekitar lingkungan hidupnya. Peristiwa konkret yang dijadikan latar belakang oleh penyair dalam penciptaan sebuah puisi sangat beragam, di antaranya dapat berupa keadaan sosial dan keadaan politik yang terjadi dalam lingkungan masyarakat. Adapun salah satu penyair yang 
melakukan penciptaan puisi dengan memperhatikan keadaan sosial dan politik lingkungan masyarakatnya adalah Wiji Thukul.

Wiji Thukul merupakan seorang yang lebih dikenal sebagai aktivis hak asasi manusia daripada sebagai penyair. Akan tetapi, walaupun keberadaan Wiji Thukul lebih dikenal sebagi aktivis hak asasi manusia, Wiji Thukul juga sangat aktif dan produktif dalam menulis puisi. Bahkan, puisi-puisi yang pernah ditulis oleh Wiji Thukul dibukukan dalam sebuah antologi puisi Nyanyian Akar Rumput.

Kumpulan puisi-puisi Wiji Thukul dalam antologi Nyanyian Akar Rumput merupakan kumpulan puisi yang menggambarkan tentang realita kemasyarakatan pada zaman orde baru. Orde baru merupakan sebutan untuk masa pemerintahan yang dipimpin oleh Soeharto sebagai presiden. Pada zaman tersebut, sistem pemerintahan dikelola secara otoriter, sehingga pemerintah banyak melahirkan kebijakan-kebijakan yang tidak berpihak kepada masyarakat. Kebijakan-kebijkan tersebut menyebabkan masyarakat tidak mendapatkan keadilan dan kehilangan hak asasinya.

Atas dasar itulah, Wiji Thukul yang menjadi bagian dari masyarakat dan berperan sebagai aktivis hak asasi manusia, meneriakkan dan menyuarakan perlawanannya melalui puisi-puisi yang terhimpun dalam antologi puisi Nyanyian Akar Rumput. Puisi-puisi yang terhimpun dalam antologi puisi Nyanyian Akar Rumput tersebut dibaca dan dideklarasikan di setiap acara-acara lembaga nonpemerintahan yang juga bersebrangan dengan sistem pemerintahan orde baru. Pembacaan dan pendeklarasian puisi-puisi tersebut dilakukan oleh Wiji Thukul dengan tujuan untuk menumbangkan sistem pemerintahan otoriter pada zaman orde baru. Akan tetapi, tujuan Wiji Thukul untuk menumbangkan sistem pemerintahan yang otoriter tersebut tidak dapat tercapai dengan baik. Bahkan, niat tersebut mengakibatkan kebradaan Wiji Thukul menjadi terancam karena dikejar-kejar dan dicari oleh aparat pemerintahan. Dalam keadaan tersebut, nama Wiji Thukul pun mencuat, wajahnya terpampang di koran-koran dan televisi sebagai orang yang paling dicari oleh aparat.

Dalam masa pengejaran dan pencariannya oleh aparat pemerintahan, Wiji Thukul bersembunyi dan berpindah-pindah dari kota ke kota. Berdasarkan buku "Teka-Teki Orang Hilang” yang ditulis oleh Tim Majalah Tempo, Wiji Thukul pernah melakukan persembunyian di hotel Borobudur Magelang, di kompleks Korpri Kalimantan Barat, di rumah 
kontrakan Tangerang, Banten, dan rumah susun Tanah Tinggi, Jakarta Pusat. Selain itu, dalam persembunyiannya Wiji Thukul juga pernah singgah di rumah rekan-rekannya yang prodemokrasi. Walaupun Wiji Thukul sedang melakukan persembunyian, Wiji thukul tetap gencar melakukan aksinya untuk menentang sistem pemerintahan orde baru pimpinan Soeharto.

Setelah sekian lama melakukan persembunyian dengan menyinggahi beberapa kota, akhinya Wiji Thukul dikabarkan hilang sampai dengan hari ini. Penghilangan Wiji Thukul tersebut tentunya disebabkan karena Wiji Thukul dianggap sebagai aktivis yang berbahaya. Anggapan tersebut muncul karena Wiji Thukul merupakan seorang aktivis yang melakukan aksi perlawanan secara langsung. Selaian dengan melakukan aksi perlawanan secara langsung, Wiji Thukul juga melakukan aksi perlawanannya dengan menulis puisi-puisi yang mendatangkan kepanikan bagi pemerintahan orde baru. Kepanikan tersebut dipicu karena puisi-puisi yang ditulis oleh Wiji Thyukul tersebut dikhawatirkan dapat memprovokasi masyrakat untuk melakukan perlawanan.

Kasus penghilangan Wiji Thukul yang disebabkan karena puisi-puisinya tersebut merupakan hal yang menarik untuk dikaji lebih mendalam. Kasus tersebut mendorong rasa ingin tahu tentang bagaimana kekuatan nilai sosial dan nilai politik yang dibentuk oleh Wiji Thukul bersama rekan-rekannya dalam puisi tersebut. Oleh karena itu, perlu dilakukan sebuah penelitian ilmiah terhadap puisi-puisi karya Wiji Thukul yang terhinpun dalam antologi Nyanyian Akar Rumput.

Dalam penelitian ilmiah sastra, pengkajian puisi hendaklah diawali dengan penafsiran terhadap teks puisi tersebut. Oleh karena itu, sebelum melakukan pendeskripsian tentang nilainilai puisi Wiji Thukul dalam antologi puisi Nyanyian Akar Rumput, terlebih dahulu akan dilakukan penafsiran terhadap teks-teks puisi tersebut melalui konsep hermeneutika. Adapun penafsiran melalaui konsep hermeneutika ini merupakan pembacaan retroakrif yang bertujuan untuk menelaah dan mengupas makna dari puisi-puisi tersebut secara menyeluruh sehingga didapatkan pemahaman yang memadai. Setelah mendapatkan pemahaman yang memadai tentang makna dari puisi-puisi tersebut, maka barulah dapat ditemukan nilai-nilai yang terkandung di dalamnya. Oleh karena itu, penelitian ini pun bertujuan untuk memaparkan 
bentuk-bentuk nilai sosial dan nilai politik puisi-puisi karya Wiji Thukul dalam antologi puisi Nyanyian Akar Rumput.

\section{Metode Penelitian}

Penelitian ini termasuk ke dalam penelitian pustaka. Hal tersebut dikarenakan objek dalam penelitian ini merupakan teks karya sastra. Oleh karena itu, proses pengumpulan data dalam penelitian ini hanya dilakukan dengan cara berhadapan langsung dan membaca teks yang berkaitan dengan sumber data. Sumber data dalam penelitian ini diperoleh dari antologi puisi Nyanyian Akar Rumput karya Whiji Thukul yang diterbitkan oleh PT Gramedia Pustaka Utama pada tahun 2015.

Adapun metode pengumpulan data yang digunakan dalam penelitian ini adalah metode studi pustaka dan observasi. Studi pustaka merupakan pengumpulan data dengan mengadakan studi penelaah terhadap buku-buku, literatur-literatur, catatan-catatan, dan laporan-laporan yang ada hubungannya dengan masalah yang akan dipecahkan (Nazir 2013: 93). Sedangkan metode observasi adalah melihat dan mengamati suatu kejadian (tari, permainan, tingkah laku, nyanyian, dll) dari gejala luarnya sampai ke dalamnya dan menggambarkan atau mendeskripsikan secara tepat hasil pengamatannya (Taum 2011: 239). Adapun metode studi pustaka dilakukan dengan cara mengumpulkan bahan-bahan literasi yang berkaitan dengan Wiji Thukul, sedangkan observasi dilakukan dengan cara membaca dan mengidentifikasi. Selanjutnya, apabila data dalam penelitian ini telah terkumpul, langkah berikutnya adalah analisis data. Adapun metode analisis data yang digunakan dalam penelitian ini adalah metode deskriptif analisis. Metode deskriptif analisis adalah metode yang dilakukan dengan cara mendeskripsikan fakta-fakta yang kemudian dianalisis ( Ratna: 2015: 53).

\section{Hasil dan Pembahasan}

\section{Nilai Sosial}

Nilai sosial puisi-puisi karya Wiji Thukul dalam antologi puisi Nyanyian Akar Rumput mempunyai bentuk yang sangat beragam. Nilai sosial puisi-puisi yang ditemukan dalam proses penelitian ini berkaitan dengan tanggung jawab, kepedulian, dan keadilan. Berikut akan 
dipaparkan kutipan dari masing-masing bentuk nilai sosial yang ditemukan dalam puisi-puisi karya Wiji Thukul dalam antologi puisi Nyanyian Akar Rumput.

\section{Tanggung Jawab}

Tanggung jawab merupakan kesadaran setiap orang akan kewajiban yang dipikulnya. Kewajiban tersebut muncul atas dasar apa yang telah dilakukan atau diputuskan oleh penanggung jawab tersebut. Seperti contoh, ketika seseorang memutuskan diri untuk bersekolah, maka ia harus bertanggung jawab dengan cara belajar. Berikut kutipan puisi-puisi karya Wiji Thukul dalam antologi puisi Nyanyian Akar Rumput yang menggambarkan tentang tanggung jawab.

"kami bermimpi punya rumah untuk anak-anak

tapi bersama hari-hari pengap yang menggelinding

kami harus angkat kaki

karena kami adalah gelandangan"

Kutipan larik di atas terdapat pada puisi yang berjudul suara di rumah-rumah miring. Secara keseluruhan, puisi tersebut terdiri atas dua puluh tiga larik. Akan tetapi larik yang dikutip di atas hanya empat larik, yakni larik ke dua puluh sampai dua puluh tiga. Kutipan larik-larik puisi tersebut mengandung nilai sosial yang berupa tanggung jawab. Hal ini dapat diketahui melalui larik ke dua puluh. Larik ke dua puluh yang berbunyi kami bermimpi punya rumah untuk anak-anak menggambarkan tentang harapan orang tua yang ingin memberikan anak-anaknya rumah yang layak. Munculnya harapan tersebut tentunya didasari atas kesadaran orang tau akan tanggung jawabnya terhadap anak-anak meraka. Akan tetapi, harapan tersebut tidak tercapai dikarenakan mereka hanyalah kaum gelandangan yang tempat tinggalnya selalu berpindah-pindah.

\section{Kepedulian}

Kepedulian merupakan bentuk sikap perhatian yang ditunjukkan oleh seseorang kepada orang lain atau terhadap kondisi sekitar. Sikap perhatian tersebut tentunya didasari oleh adanya hubungan emosional yang sangat kuat antara orang yang memerhatikan dan orang yang diperhatikan. Berikut kutipan puisi-puisi karya Wiji Thukul dalam antologi puisi Nyanyian Akar Rumput yang menggambarkan tentang kepedulian. 


\section{"aku jalan lagi \\ melewati rumah yang pernah disewa \\ riyanto buruh kawan sekerjaku \\ ke mana dia lagi sekeluarga"}

Larik pada kutipan tersebut terdapat pada puisi yang berjudul lumut. Puisi yang berjudul lumut ini terdiri atas dua puluh lima larik. Akan tetapi, larik yang dikutip hanyalah larik ke lima sampai larik ke delapan. Kutipan larik-larik puisi tersebut mengandung nilai sosial yang berbentuk kepedulian. Hal tersebut dapat diketahui melalui larik ke tujuh dan delapan yang berbunyi riyanto buruh kawan sekerjaku // ke mana dia lagi sekeluarga. Dalam larik tersebut terlihat bahwa Wiji Thukul yang meneyebut dirinya sebagai aku memberikan sikap perhatian kepada kawan sekerjanya yakni riyanto. Sikap perhatian tersebut merupakan bentuk suatu kepedulian yang diberikan oleh Wiji Thukul kepada teman sekerjanya. Adapun kepedulian tersebut tercermin ketika Wiji Thukul menanyakan tentang keberadaan riyanto dan keluarganya.

\section{Keadilan}

Keadilan merupakan sikap tidak memihak yang dilakukan oleh seseorang dalam memutuskan suatu hal atau perkara. Oleh karena itu, keadilan merupakan suatu hal yang sangat penting dalam kehidupan bermasyarakat. Dengan diterapkannya keadilan, masyarakat akan mendapatkan perlakuan sesuai dengan hak dan kewajibannya. Adapun kutipan puisi-puisi karya Wiji Thukul dalam antologi puisi Nyanyian Akar Rumput yang menggambarkan tentang keadilan adalah sebagai berikut.

"ibu akan marah besar

\section{bila kami merebut jatah makan}

yang bukan hak kami”

Larik pada kutipan di atas terdapat pada puisi yang berjudul sajak ibu. Puisi tersebut terdiri atas dua puluh empat larik. Akan tetapi, larik yang dikutip untuk dijadikan bahan analisis tentang keadilan hanyalah tiga larik, yakni dimulai dari larik ke lima sampai larik ke tujuh. Tiga larik puisi yang dikutip tersebut menunjukkan bahwa larik-larik puisi tersebut mengandung nilai sosial yang berupa keadilan. Larik-larik puisi tersebut menggambarkan tentang anak yang merasa takut dimarahi ibunya ketika hendak berandai-andai untuk merebut 
jatah makan yang bukan hak mereka. Perasaan takut yang dialami oleh anak tersebut tentunya didasari oleh tegasnya ajaran yang disampaikan oleh ibu mereka tentang keadilan. Sikap keadilan yang diajarkan oleh sang ibu membuat mereka takut untuk mengambil sesuatu yang bukan menjadi hak dan porsi mereka.

\section{Nilai Politik}

Nilai politik pusi-puisi karya Wiji Thukul dalam antologi Nyanyian Akar Rumput juga mempunyai bentuk yang sangat beragam. Adapun bentuk-bentuk nilai sosial yang ditemukan dalam puisi-puisi puisi karya Wiji Thukul dalam antologi Nyanyian Akar Rumput berkaitan dengan perjuangan, persuasi, dan protes. Berikut akan dipaparkan kutipan dari masing-masing bentuk nilai politik yang ditemukan dalam puisi-puisi karya Wiji Thukul dalam antologi puisi Nyanyian Akar Rumput.

\section{Perjuangan}

Perjuangan merupakan upaya yang dilakukan oleh seorang pejuang untuk mencapai suatu tujuan yang dihendaki. Dalam proses pencapaian tujuan tersebut, seorang pejuang biasanya akan dihadapkan dengan berbagai rintangan. Oleh karena itu, perjuangan membutuhkan sebuah mental yang kuat. Adapun kutipan puisi-puisi karya Wiji Thukul dalam antologi puisi Nyanyian Akar Rumput yang menggambarkan tentang perjuangan adalah sebagai berikut.

"suara-suara itu tak bisa dipenjarakan

di sana bersemayam kemerdekaan

apabila kau memaksa diam

aku siapkan untukmu pemberontakan!"

Larik pada kutipan di atas terdapat pada puisi yang berjudul sajak suara. Puisi yang berjudul sajak suara ini terdiri atas dua puluh larik. Adapun kutipan di atas diambil dari larik ke enam sampai larik ke delapan. Pada larik-larik puisi di atas terdapat sebuah nilai politik yang berbentuk perjuangan. Perjuangan tersebut tergambar pada larik ke lima dan ke enam yang berbunyi suara-suara itu tak bisa dipenjarakan // di sana bersemayam kemerdekaan. Maksud dari frasa suara-suara pada larik tersebut adalah kritikan, sedangkan kata dipenjarakan pada akhir larik tersebut berarti dibungkam. Oleh karena itu, dapat dipahami bahwa larik ke lima dan ke enam pada puisi tersebut menggambarkan tentang ketagasan Wiji Thukul sebagai pengarang yang tidak ingin kritiknya terhadap pemerintah dibungkam. 
Adapun kritik-kritik terhadap pemerintah yang disuarakan oleh Wiji Thukul tersebut merupakan suatu bentuk perjuangan atas ketidakadilan yang dirasakannya terhadap kebijakankebijkan pemerintah orde baru. Melalui kritik-kritik yang disuarakan itulah, Wiji Thukul yang sekaligus menjadi pengarang puisi tersebut berupaya untuk menumbangkan sistem pemerintahan orde baru yang tidak dapat memberikan kemerdekaan. Selanjutnya, pada larik ke tujuh dan ke delapan Wiji Thukul kembali menegaskan bahwa ia akan melakukan pemberontakan terhadap pemerintah apabila kritik-kritik yang disampaikannya dibungkam paksa.

\section{Persuasi}

Persuasi merupakan sebuah ajakan yang disampaikan oleh seseorang kepada orang lain. Ajakan tersebut berisi tentang upaya-upaya untuk mempengaruhi orang lain agar memiliki kesepahaman terhadap apa yang disampaikan oleh orang yang mengajak. Berikut kutipan puisi-puisi karya Wiji Thukul dalam antologi puisi Nyanyian Akar Rumput yang menggambarkan tentang persuasi.

"apabila usul ditolak tanpa ditimbang

suara dibungkam kritik dilarang tanpa alas an

dituduh subversif dan mengganggu keamanan

maka hanya ada satu kata: lawan!"

Kutipan larik-larik di atas terdapat pada puisi yang berjudul peringatan. Puisi yang berjudul peringatan ini terdiri atas tujuh belas larik. Adapun larik yang dikutip tersebut terdapat pada larik ke empat belas sampai tujuh belas. Puisi ini mengandung nilai politik yang berupa persuasi. Hal ini dapat diketahui melalui kata terakhir pada larik ke tujuh belas dari puisi tersebut. Pada baris ke tujuh belas tersebut, Wiji Thukul sebagai orang yang menulis puisi ini mengajak kepada rekan-rekannya untuk melawan. Ajakan untuk melawan yang dideklamasikan oleh Wiji Thukul ini tentunya ditujukan kepada pemerintah orde baru apabila usul-usul mereka ditolak tanpa ditimbang, kritik-kritik mereka dilarang tanpa alasan, dan dituduh mengganggu keamanan. Hal tersebut dapat diketahui melalui larik ke empat belas sampai ke enam belas pada puisi yang berjudul peringatan. 


\section{Protes}

Protes merupakan sebuah reaksi ketidakpuasan terhadap suatu pelayanan atau kebijakan yang diputuskan. Dalam kehidupan bermasyarakat, reaksi ketidakpuasan tersebut muncul karena ketidakadilan yang didapatkan oleh seseorang yang melakukan protes. Oleh karena itu, protes biasanya dilakukan oleh sekelompok masyarakat yang merasa tidak mendapatkan keadilan atas kebijakan yang diputuskan oleh pemerintah. Berikut kutipan puisi-puisi karya Wiji Thukul dalam antologi puisi Nyanyian Akar Rumput yang menggambarkan tentang protes.

"dan upah kami dalam waktu singkat telah berubah menjadi odol-sampo-sewa rumah dan bon-bon di warung yang harus kami lunasi"

Kutipan larik-larik di atas terdapat pada puisi yang berjudul teka-teki ganjil. Puisi yang berjudul teka-teki ganjil ini merupakan puisi Wiji Thukul yang cukup panjang. Puisi tersebut terdiri atas lima puluh delapan larik yang terpola menjadi sembilan bait. Adapun kutipan lariklarik di atas diambil dari bait ke dua pada larik ke empat belas sampai dengan larik ke enam belas. Pada kutipan larik tersebut terkandung sebuah nilai politik yang berupa protes. Hal tersebut dapat diketahui melalui larik ke empat belas dan ke lima belas yang berbunyi dan upah kami dalam waktu singkat telah berubah // menjadi odol-sampo-sewa rumah. Maksud kata kami pada larik ke empat belas tersebut berarti Wiji Thukul dan rekan-rekannya yang berprofesi sebagai buruh pabrik. Oleh karena itu, dapat disimpulkan bahwa protes yang dimaksud dalam kutipan larik-larik tersebut merupakan protes atas ketidakpuasan kaum buruh dengan upah yang mereka dapatkan. Adapun ketidakpuasan akan upah yang mereka dapatkan tersebut distandarkan dengan harga-harga kebutuhan hidup yang mahal, sehingga upah yang mereka dapatkan akan habis dalam waktu yang singkat.

\section{Simpulan}

Berdasarkan hasil analisis data yang telah dilakukan, wujud nilai sosial yang ditemukan pada puisi-puisi karya Wiji Thukul dalam antologi puisi Nyanyian Akar Rumput berbentuk tanggung jawab, kepedulian, dan keadilan. Sedangkan wujud nilai politik yang ditemukan pada puisi-puisi karya Wiji Thukul dalam antologi puisi Nyanyian Akar Rumput berbentuk perjuangan, persuasi, dan protes. Adapun bentuk nilai sosial yang paling banyak ditemukan 
adalah tentang kepedulian. Sedangkan bentuk nilai politik yang paling banyak ditemukan adalah tentang protes.

\section{Daftar Pustaka}

Anwar. 2017. Sosiologi. Bandung. Refika Aditama.

Arikunto. 2014. Prosedur penelitian (Suatu Pendekatan Praktik). Jakarta. Rineka Cipta.

Bustomi. (2015). Nyanyian Akar Rumput Kumpulan Lengkap Puisi Wiji Thukul. Jakarta. PT Gramedia Pustaka Utama.

Davurger. 2014. Sosiologi Politik. Depok. PT. Rajagrafindo Persada.

Elmubarok. 2013. Membumikan Pendidikan Nilai. Bandung. Alfabeta.

Endraswara. 2013. Prinsip, Falsafah, dan Penerapan Teori Kritik Sastra. Jakarta. PT. Buku Seru.

Faulks. 2015. Sosiologi Politik. Bandung. Nusa Media.

Gadamer. 2010. Kebenaran dan Metode. Yogyakarta. Pustaka Belajar.

Nazir. (2013). Metode Penelitian. Bogor. Ghalia Indonesia.

Ratna. (2015). Teori, Metode, dan Teknik Penelitian Sastra dari Strukturalisme Hingga Postrukturalisme Perspektif Wacana Narataif. Yogyakarta. Pustaka Pelajar.

Taum. (2011). Studi Sastra Lisan. Yogyakarta. Lamalera. 